\title{
Discrete cortical representations and their stability in the presence of synaptic turnover
}

\author{
Bastian Eppler ${ }^{1,2^{*}}$, Dominik Aschauer ${ }^{3}$, Simon Rumpel ${ }^{3}$, Matthias Kaschube ${ }^{1,2}$ \\ From 24th Annual Computational Neuroscience Meeting: CNS*2015 \\ Prague, Czech Republic. 18-23 July 2015
}

Population imaging in mouse auditory cortex revealed clustering of neural responses to brief complex sounds: the activity of a local population typically falls close to one out of a small number of observed states [1]. These clusters appear to group sets of auditory stimuli into a discrete set of activity patterns and could thereby form the basis for representations of sound categories. However, to be useful for the brain, such representations should be robust against fluctuations in the underlying circuitry, which are significant even in the absences of any explicit learning paradigm [2]. Here we introduce a novel firing rate based circuit model of mouse auditory cortex to study the emergence of the observed activity cluster states and their structural stability in the presence of synaptic noise. We find that generic random networks by virtue of their inhibitory recurrent connectivity can group complex sounds spontaneously into essentially discrete sets of activity states. Moreover, these states can display high degrees of stability, even when modifying a substantial fraction of synaptic connections, as long as the basic statistics of connectivity is maintained. We use the insights gained from the analysis of our model to interpret data gathered in a parallel effort, employing chronic two-photon imaging of population activity in the auditory cortex of awake mice.

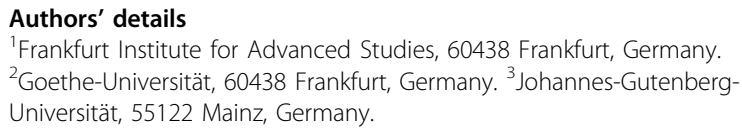

Published: 18 December 2015

\section{References}

1. Bathellier B, Ushakova L, Rumpel S: Discrete neocortical dynamics predict behavioral categorization of sounds. Neuron 2012, 76(2):435-49.

2. Loewenstein $Y$, Kuras A, Rumpel S: Multiplicative dynamics underlie the emergence of the log-normal distribution of spine sizes in the neocortex in vivo. J Neurosci 2011, 31(26):9481-8.

doi:10.1186/1471-2202-16-S1-P114

Cite this article as: Eppler et al:: Discrete cortical representations and their stability in the presence of synaptic turnover. BMC Neuroscience 2015 16(Suppl 1):P114.

* Correspondence: eppler@fias.uni-frankfurt.de

${ }^{1}$ Frankfurt Institute for Advanced Studies, 60438 Frankfurt, Germany

Full list of author information is available at the end of the article

Submit your next manuscript to BioMed Central and take full advantage of:

- Convenient online submission

- Thorough peer review

- No space constraints or color figure charges

- Immediate publication on acceptance

- Inclusion in PubMed, CAS, Scopus and Google Scholar

- Research which is freely available for redistribution
C Biomed Central

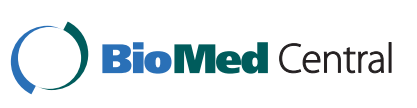

(c) 2015 Eppler et al. This is an Open Access article distributed under the terms of the Creative Commons Attribution License (http:// creativecommons.org/licenses/by/4.0), which permits unrestricted use, distribution, and reproduction in any medium, provided the original work is properly cited. The Creative Commons Public Domain Dedication waiver (http://creativecommons.org/publicdomain/ zero/1.0/) applies to the data made available in this article, unless otherwise stated. 